\title{
Improving the Performance of Single Cells in the Design of Proton Exchange Membrane Fuel Cell (PEMFC) when Using Hydrogen
}

\author{
Mulyazmi ${ }^{\#}$, Maria Ulfah", Silvi Octavia ${ }^{\#}$ \\ ${ }^{\#}$ Department of Chemical Engineering, University of Bung Hatta \\ Padang, West Sumatera, Indonesia \\ Email:mulyazmi@yahoo.com
}

\begin{abstract}
A proton Exchange Membrane Fuel Cell (PEMFC) was developed as a potential solution in power supply applications. In this study, the parameter values such as the relative humidity, the temperature, the pressure, the stoichiometric ratio of hydrogen to oxygen and the mass of catalyst used were varied to determine their effects on the single cell performance of PEMFC. The investigation showed that an increase in the temperature from 353 to $363 \mathrm{~K}$ resulted in a modest improvement in the single-cell performance. The single cell performance was more affected by an increase in relative humidity at the cathode (RHC) in comparison with an increase in relative humidity at the anode (RHA).The best performance when the cell was operated at relative humidity values were $75 \%$ for the RHA and $90 \%$ for the RHC, the optimal operating temperature was $353 \mathrm{~K}$, and the amount of Pt catalyst required was $0.2 \mathrm{mg}$.
\end{abstract}

Keywords - PEMFC; modelling; single cell; performance; design system

\section{INTRODUCTION}

Fuel cells are electrochemical devices that convert chemical energy from fuel (hydrogen) and oxidant (oxygen or air) directly into electrical energy and thermal energy, producing water as a byproduct. One type of fuel cell is the PEMFC, which can be operated at low temperatures to produce electrical energy. Developing the system performance of PEMFC requires a suitable design and appropriate technology. The main purpose is to achieve optimal performance and obtain a low-cost PEMFC system.

Some parameters in the PEMFC system are associated with other parameters in the system. These parameters consist of the operating conditions, the design of the membrane electrolyte assembly (MEA) and the stack PEMFC [1]. The performance of the PEMFC is evaluated in the form of the voltage generated, the power density and the efficiency. The optimal performance of the cells is influenced by many internal and external factors, such as the fuel cell design and assembly, the degradation of materials, the operating conditions and the impurities or the contaminants [2]. Other parameters such as the pressure, temperature, composition and utilization of the fuel, and composition and the utilization of oxidant can be varied simultaneously to achieve the desired operating point. Much research has been conducted to develop the operating conditions in the design of PEMFC. Mulyazmi [3] studied the performance of PEMFC which are influenced by the operating temperature, pressure, and humidity of the reactant gas to the effects of mass transport in membranes and the transportation of the water produced at the stack fuel cell. Ozen et al.[4] Investigated the effects of operating conditions such as humidification, stack temperature, and flow gas on the individual cells and a stack of PEMFC. The operating parameters that facilitated better water removal rates by a temperature, stoichiometric and pressure resulted in the generation of a higher net current [5]. The use of a system design for PEM fuel cells allows for the manipulation of parameters to obtain the best combination of system variables. Abdin et al. [6] and Salva et al. [7] investigated the optimal conditions PEMFC based on temperature, pressure, and humidity on cell and ratio stoichiometry. The PEMFC central system must be supported by providing an oxidant supply (oxygen or air), a fuel supply (hydrogen), heat and water management, process control, equipment and supervision [8], [9]. The many failures in PEMFC systems include flooding, the diffusion of water in stack fuel cell and poor of integration heat and mass during the operation [10] . Mulyazmi et al [3] conducted a study on water balance in PEMFC stack. Then get to know the effect of various operating conditions of optimum performance PEMFC system. The focus of this research was to develop a fundamental thermodynamic basis for developing a modelling system to optimize the performance of PEMFC systems. The next focus was to determine the 
influence of system parameters such as the temperature, operating pressure, relative humidity and stoichiometry of the reactants entering the PEMFC cell stack on the voltage and the current density that was produced by the resulting fuel cell system.

\section{MATERIAL AND METHOD}

The model was developed based on several assumptions:

- There are negligible pressure drops in the PEMFC stack.

- The reactant gases in the system possess ideal gas behaviors.

- The PEMFC system operates at steady state.

- The water flowing into the stack is in the gas phase.

- The operation of the PEMFC stack is an isothermal process.

The voltage value of each cell in a PEMFC stack is determined by the maximum value of the voltage cells and the loss of voltage. The loss of voltage in fuel cells includes activation loss, ohmic resistance loss, concentration loss and the loss of internal currents. The cell voltage value $V_{\text {oper }}$ on in the operation of a PEMFC is:

$$
\begin{gathered}
V_{\text {oper }}=V_{\text {rev }}-V_{\text {irrev }} \\
V_{\text {irev }}=V_{a c t}-V_{\text {ohm }}-V_{\text {con }}
\end{gathered}
$$

\section{A. Reversible Voltage ( $\left.V_{\text {rav }}\right)$}

The reversible cell voltage is the maximum theoretical potential of a fuel cell and is independent of the loading in a fuel cell. The free energy change is a measure of the maximum electrical work that can be obtained from a system at a fixed reaction temperature and pressure. The reversible voltage in a PEMFC is:

$$
V_{r e f}=E_{T}+\frac{F T}{F_{n}} \ln \left[\frac{P_{\mathrm{H}_{2}} 2\left[F_{\mathrm{O}_{2}}{ }^{0.5}\right]}{P_{\mathrm{H}_{2} \mathrm{O}}}\right]
$$

$P_{l}$ is the partial pressure (atm). The electrical potential at standard conditions is: $E^{0}=-\frac{\Delta q}{n F}$. The electrical potential $E_{T}$ is:

$$
E_{T}=1.229 \mathrm{~V}-0.85 \times 10^{-2}\left(T-T_{\text {ref }}\right) \frac{V}{R}
$$

The reversible voltage in the PEMFC can be obtained by substituting equation (3) into equation (4), with the assumption that the partial pressure of water is 1 atm because it exists as a liquid [11]:

$$
\begin{aligned}
& V_{\text {rev }}= \\
& 1.229 V-0.85 \times 10^{-3}\left(T-T_{r e f}\right)+ \\
& 10^{-5} \times T \times \ln \left(P_{H_{2}} \times\left(P_{O_{2}}{ }^{05}\right)\right)
\end{aligned}
$$

\section{B. Activation Voltage ( $V_{\text {act }}$ )}

The current density can then be written as:

$$
i=n F\left(k_{f} C_{O_{2}}-k_{n} C_{H_{2}}\right)
$$

Equation (6), which is also known as the Volmer Butler equation, the reaction concentration becomes [12]:

$$
\bar{i}=n F\left(k_{f, 0} \operatorname{erp}\left(\frac{-\mathrm{aFE}}{\mathrm{RT}}\right) C_{O_{2}}-k_{\delta, 0} \exp \left(\frac{\mathrm{C}-\mathrm{RFE}}{\mathrm{RT}}\right) C_{H_{2}}\right)
$$

The change in the current density is:

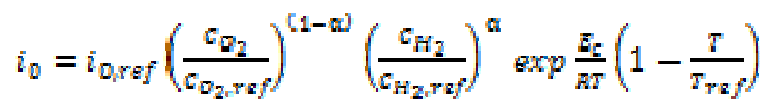

The $i_{0}$ value influenced by the reaction surface area per unit volume of the catalyst layer $(a)$ is

$$
i_{0}=a i_{0 r g f}\left(\frac{F_{R} Y}{p_{R_{t} r z f}}\right) \exp \frac{E_{c}}{N T}\left(1-\frac{T}{T_{r a f}}\right)
$$

$\boldsymbol{R}=$ reactant $\left(\mathrm{H}_{2}\right.$ and $\left.\mathrm{O}_{2}\right)$ and $\boldsymbol{E}_{\mathrm{q}}=$ activation energy $(76.5$ $\mathrm{kJ} / \mathrm{mol}$ ) . Song [13] defined the value of $\boldsymbol{a}$ as:

$$
a=a_{0} \frac{n_{p r}}{2}
$$

The value of $a_{0}$ was determine by Song [14] to be:

$$
\begin{gathered}
a_{0}=10^{8}\left(4.4198 Y^{9}-27.691 Y^{8}+74.206 Y^{Z}-\right. \\
111.06 Y^{2}+101.43 Y^{5}-57.841 Y^{4}+ \\
\left.20.231 Y^{2}-4.089 Y^{2}+0.39451 Y\right) \\
(11)
\end{gathered}
$$

Where $\mathrm{Y}=\%$ Pt. According to Inoue [15], the reference current density is:

$$
i_{0 r e f}=10^{\left(2.057-\frac{4001}{T}\right)}
$$

If $\bar{z}$ is compared with $\bar{z}_{0}$ is:

$$
\begin{aligned}
& \frac{i}{i_{2}}=\frac{C_{D_{1}}}{C_{D_{2}}}\left(\exp \left(\frac{-\mathrm{AFE}}{\mathrm{RT}}\right)+\left(\frac{\mathrm{GFE}_{\mathrm{r}}}{\mathrm{RT}^{2}}\right)\right)-\left(\exp \left(\frac{-\mathrm{GFE}}{\mathrm{RT}}\right)+\right. \\
& \left.\left(\frac{\mathrm{CFE}}{\mathrm{BT}}\right)\right)
\end{aligned}
$$

$$
\begin{aligned}
& \mathbf{E}-\mathbf{E}_{\mathrm{r}}=\eta_{\mathrm{art}}, \frac{i}{i_{0}} \text { value became: } \\
& \qquad v_{\mathrm{act}}=\frac{\mathrm{RT}}{2 \mathrm{mF}} \operatorname{sin~}^{-1}\left(\frac{i}{i_{\mathrm{g}}}\right)
\end{aligned}
$$

The voltage activation [16] is

$$
V_{\text {act }}=\frac{m}{n W F} \ln \left(\frac{i}{i_{2}}\right) \text { where } i>i_{0}
$$

From equation (15) the Tafel constant can be obtained: 


$$
b=\frac{A T}{n \alpha F}
$$

Where $b=$ the Tafel constant. According Mann [17] :

$$
b=0.1937 e^{-2-197(\alpha)}
$$

The value of the exchange coefficient value $\alpha$ was obtained from Zhang [18] :

$$
\alpha=\left(0.001552 R H_{c_{i} i n}+0.000139\right) T
$$

$R H_{c_{i} \text { in }}$ is the relative humidity of the reactants that flow into the cathode side of the stack of PEMFC.

\section{Ohmic Voltage $\left(\mathrm{V}_{\mathrm{ohm}}\right)$}

The ohmic voltage that is lost was presented:

$$
\nabla_{\text {ohm }}=i R_{\text {ohm }}
$$

where the $R_{\text {ohm }}$ value is

$$
R_{o h \mathrm{~m}}=\frac{t_{\mathrm{m}}}{\sigma_{\mathrm{m}}}
$$

The membrane proton conductivity can be written as [19]:

$$
\sigma_{\mathrm{m}}=\left(0.005139 \lambda_{\mathrm{m}}-0.003260\right) \exp \left[1268\left(\frac{1}{\mathrm{~g} 02}-\frac{1}{\mathrm{~T}}\right)\right]
$$

where $\lambda_{m}$ is the water content in the membrane:

$$
\lambda_{m}=0.048+17.81 R H-39.83 a R H^{2}+39.85 R H^{2}
$$

where $R H$ is the average relative humidity in the stack of PEM fuel cells.

\section{Concentration Voltage ( $\left.\nabla_{\text {couc }}\right)$}

The concentration voltage was presented by Shaker [20] as:

$$
V_{\text {conc }}=\operatorname{cln}\left(\frac{i_{L_{1}}}{i_{L}-1}\right)
$$

Where $c$ is the concentration loss constant. The value of $c$ is:

$$
C=\frac{R T}{\mathrm{nF}}
$$

The concentration voltage value is:

$$
V_{\text {Gue }}=\frac{R T}{n} \ln \left(\frac{i_{2}}{i_{L}-1}\right)
$$

$\bar{i}_{2}=$ is the limiting current density $\left(\frac{A}{\mathrm{Cm}^{2}}\right)$.The limiting current density is [21]

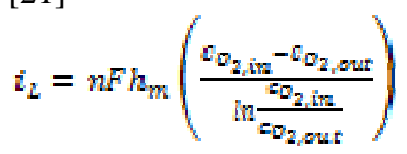

$c_{O_{2, i n a m a t}}$ is the concentration of oxygen entering and exiting a PEMFC stack (mol), and $h_{m}$ is the convective mass transfer coefficient $\left(\mathrm{m} \mathrm{s}^{-1}\right)$. The convective mass transfer coefficient can be written as [22]:

$$
h_{m}=\frac{\sin _{f} D_{i j}}{H_{s}}
$$

\begin{tabular}{|c|c|}
\hline Parameter & Value \\
\hline Cell temperature & $333 \mathrm{~K}$ to $363 \mathrm{~K}$ \\
\hline Reference temperature & $298.15 \mathrm{~K}$ \\
\hline Dry membrane thickness & $0.0051 \mathrm{~cm}$ for Nafion 112 \\
\hline Catalyst load & $0.0002 \mathrm{~g} \mathrm{~cm}^{-2}$ \\
\hline Thickness of the catalyst & $0.0005 \mathrm{~cm}$ \\
\hline Anode side pressure & $1 \mathrm{~atm}$ \\
\hline Cathode side pressure & $1 \mathrm{~atm}$ \\
\hline Relative humidity at the anode & 0.5 to 0.9 \\
\hline Relative humidity at the anode & 0.5 to 0.9 \\
\hline Universal gas constant & $8.314 \mathrm{~J} / \mathrm{mol} \mathrm{K}$ \\
\hline Faraday constant & $96,485 \mathrm{C} / \mathrm{mol}$ electrons \\
\hline Stoichiometric ratio for hydrogen & 1.2 \\
\hline Stoichiometric ratio for oxygen & 2 \\
\hline
\end{tabular}

\section{RESULTS AND DISCUSSION}

In this study, several parameters that affect the performance of single cell PEMFC have been discussed, such as the operating temperature, the relative humidity, the operating pressure, the stoichiometric ratio of the hydrogen and oxygen reactants, and the influence of the mass of catalyst that was added to the cells. The operating parameters for the base case are listed in Table 1.

TABLE I

BASE CASE MOdel PARAMETER

\section{A. The Influence of the Operating Temperature}

Fig. 1a shows the increase in the single cell performance when the operating temperature was increased from $333 \mathrm{~K}$ to $353 \mathrm{~K}$. However, a subsequent increase in the temperature from $353 \mathrm{~K}$ to $363 \mathrm{~K}$ had little effect on the single cell performance. A current density of less than $0.3 \mathrm{Acm}^{-2}$ showed that a temperature difference did not affect the power density that was produced, but current densities that exceeded $0.3 \mathrm{Acm}^{-2}$ affected the power density hat was produced when the temperature was increased $333 \mathrm{~K}$ to 353 $\mathrm{K}$; however, increasing the temperature from $353 \mathrm{~K}$ to $363 \mathrm{~K}$ did not affect the power density that was produced. Fig. 1b shows an increase in the temperature also improved the performance of the PEMFC. However, an increase in the temperature from $353 \mathrm{~K}$ to $363 \mathrm{~K}$ did not significantly affect the single cell performance. At current densities that were greater than $1 \mathrm{Acm}^{-2}$, an increase in the temperature from $353 \mathrm{~K}$ to $363 \mathrm{~K}$ did not affect the current density significantly. Figs. 1c, 1d, and 1e show that an increase in temperature from $333 \mathrm{~K}$ to $363 \mathrm{~K}$ at different operating conditions resulted in an increase in the single cell performance because there was an increased voltage and an increased power density that was generated by the PEMFC. The result of this study was an increase in the power density when the current density was greater than $0.25 \mathrm{~A} \mathrm{~cm}^{-2}$ under 
the operating conditions shown in Fig.1c, when the current density was greater than $0.4 \mathrm{~A} \mathrm{~cm}^{-2}$ under the operating conditions shown in Fig.1d, and when the current density was greater than $0.6 \mathrm{~A} \mathrm{~cm}^{-2}$ in the conditions shown in Fig. 1e. The results of this study followed the trends observed by Shamardinaetal [23], who found that an increase in operating temperature cause and improvement in the performance of PEMFC systems.

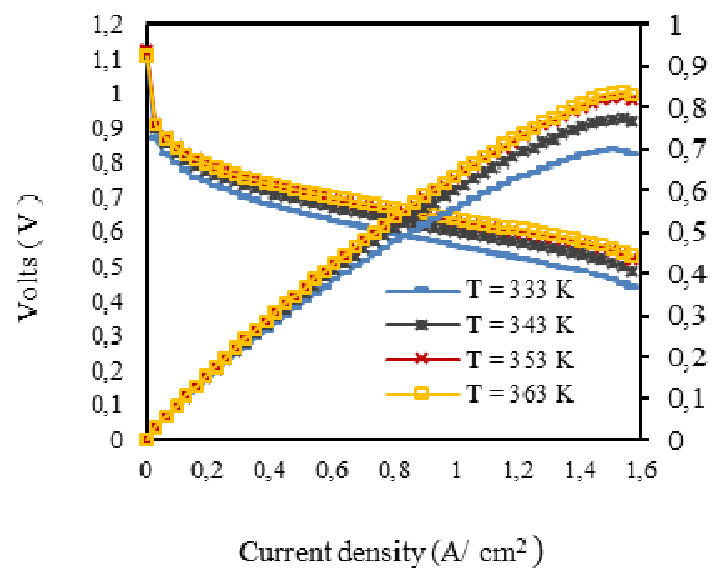

(a)

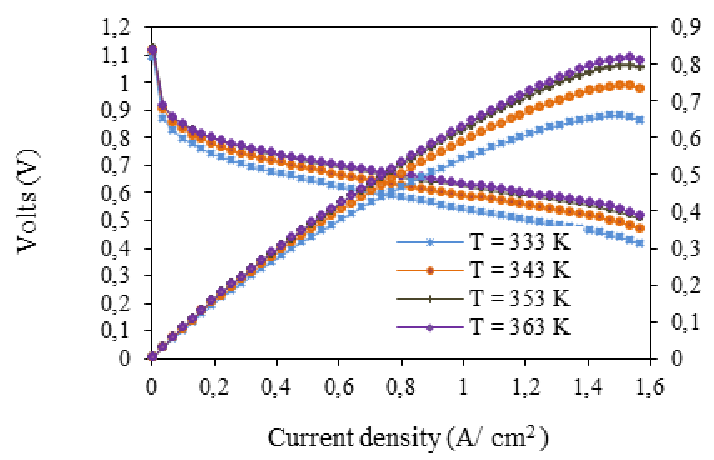

(b)

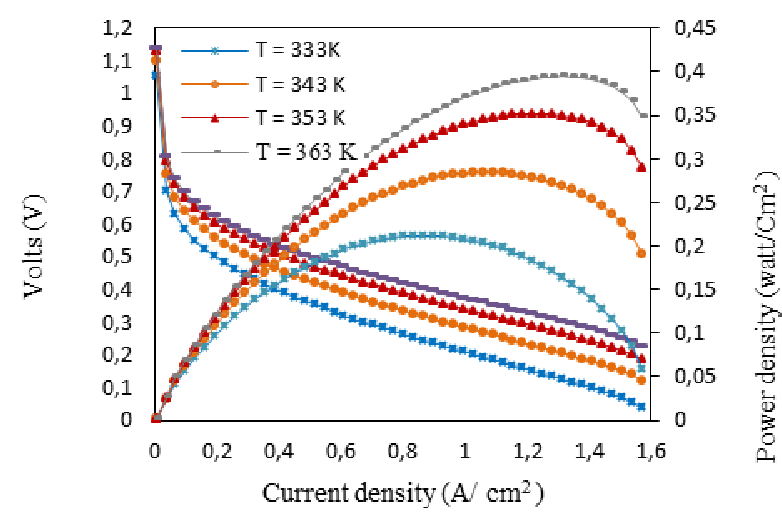

(c)

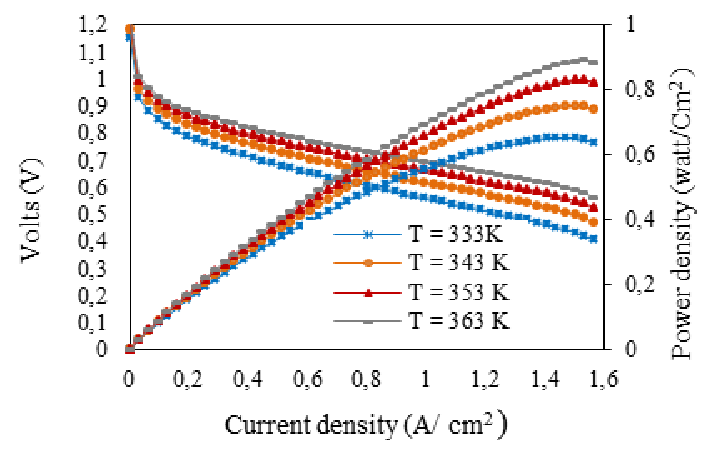

(d)

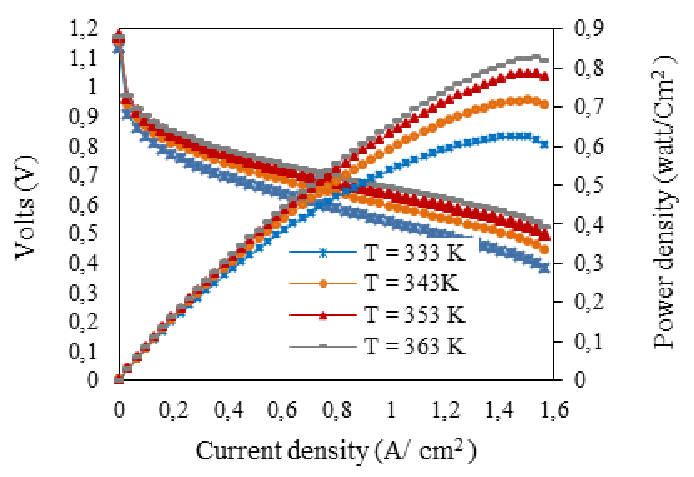

(e)

Fig. 1 Effect of operating temperature on single cell performance of PEMFC at the stoichiometric ratio of $\mathrm{H}_{2}$ is 1.2 and $\mathrm{O}_{2}$ is 2 . Other operating conditions are: (a) RHA and RHC are 90\%, PA and PC are 1 atm (b) RHA and RHC was $50 \%$ and $90 \%, \mathrm{PA}$ and $\mathrm{PC}$ are $1 \mathrm{~atm}$ (c) RHA and RHC are $90 \%$ and $50 \%, \mathrm{PA}$ and PC are 1 atm (d) RHA and RHC are $50 \%$ and $90 \%$, $\mathrm{PA}$ and PC are 1 atm and 2 atm (e) RHA and RHC are $50 \%$ and $90 \%$, PA and $\mathrm{PK}$ are $2 \mathrm{~atm}$ and $1 \mathrm{~atm}$

\section{B. The Effect of Relative Humidity on the Reactants}

Figs. $2 \mathrm{a}$ and $2 \mathrm{c}$ show the effects of varying the relative humidity while all the other conditions are kept constant. The RHA in Fig. 2a was maintained at $50 \%$ while the RHC was varied from $50 \%$ to $90 \%$. In Fig. 2c, the RHC was maintained at $50 \%$ while the RHA was varied from $50 \%$ to $90 \%$. Fig. 2a shows the improvement in the single cell performance with an increase in the RHA. Fig. 2c shows that the increase in RHA causes an insignificant improvement in the single-cell performance. Increasing the RHC was more effective than increasing the RHA with regard to improving the single cell performance. The increases in the RHA and the RHC resulted in an increased voltage and an increased power density. Specifically, an increased RHC significantly improved single cell performance. Figs. 2c, 2d and 2e show the effect of RHA on the single cell performance; improved performance occurs beyond a voltage of $0.6 \mathrm{~V}$. Figs. $2 \mathrm{a}$ and $2 \mathrm{~b}$ show the effect of maintaining the RHA at $50 \%$ and $70 \%$ while the value of RHC was kept constant from $50 \%$ to $90 \%$. 


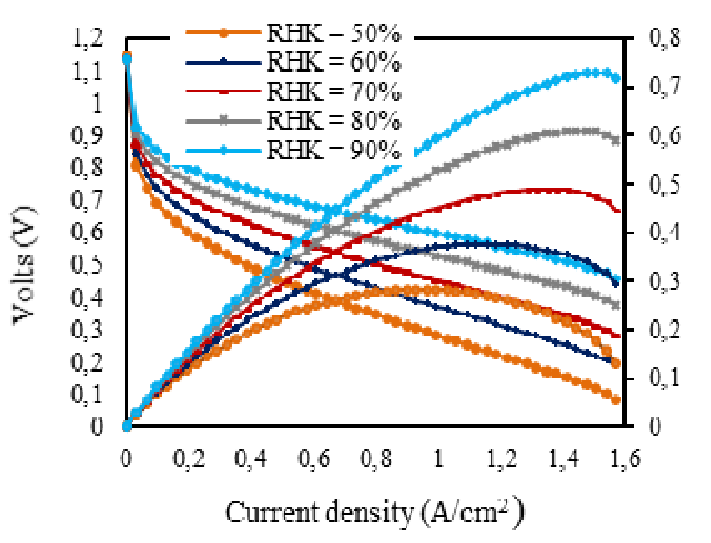

(a)

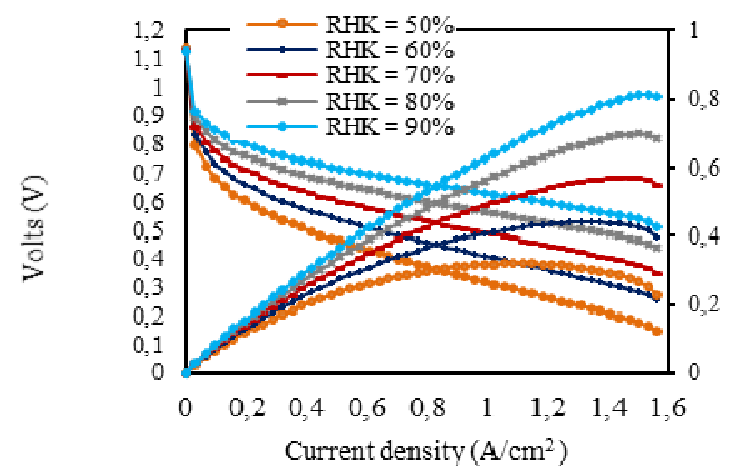

(b)

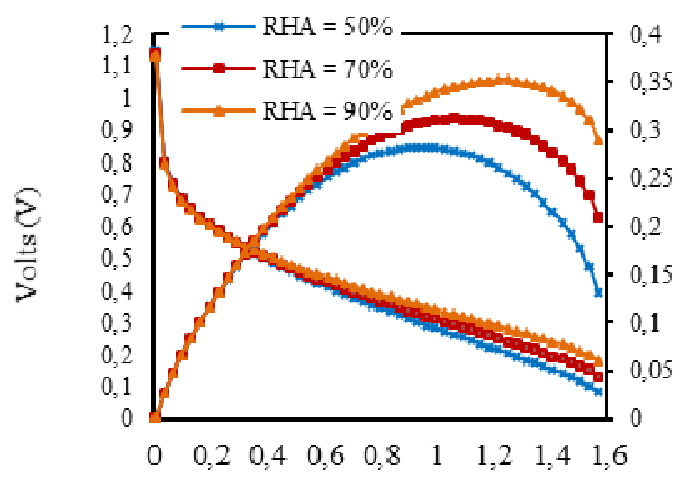

Current density $\left(\mathrm{A} / \mathrm{cm}^{2}\right)$

(c)

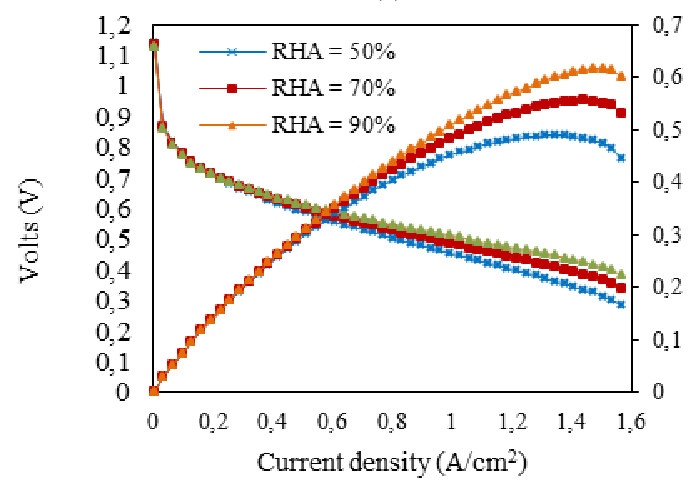

(d)

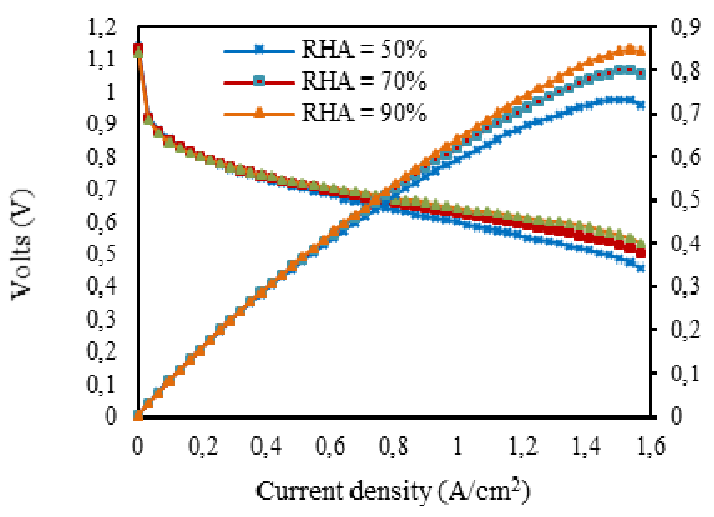

(e)

Fig. 2 Effect of relative humidity on single cell performance of PEMFC at temperatures of $353 \mathrm{~K}$, the operating pressure of $1 \mathrm{~atm}$, the stoichiometric ratio is 1.2 for $\mathrm{H} 2$ and $\mathrm{O} 2$ are 2: (a) RHA is $50 \%$ and $\mathrm{RHC}$ are $50 \%, 60 \%$, $70 \%, 80 \%$ and $90 \%$. (b) RHA is $75 \%$ and RHA are $50 \%, 60 \%, 70 \%, 80 \%$ and $90 \%$. (c) RHA is $50 \%, 70 \%$ and $90 \%$, RHC is $50 \%$. (d) RHA are $50 \%$, $70 \%$ and $90 \%$, RHC is $70 \%$.( e) RHA are $50 \%, 70 \%$ and $90 \%, \mathrm{RHC}$ is $90 \%$.

\section{The Effect of Operating Pressures}

Figs. $3 \mathrm{a}$ and $3 \mathrm{~b}$ show the performance of the single cells when the cathode and the anode pressures were varied from $1 \mathrm{~atm}$ to $2.5 \mathrm{~atm}$. An increase in anode pressure resulted in improved performance of the single cell. Increasing the cathode pressure from 2 atm to 2.5 atm did not significantly affect the single cell performance. An increased anode pressure from $1 \mathrm{~atm}$ to 2.5 atm improved the single cell performance significantly. The increase in current density at a voltage of $0.6 \mathrm{~V}$ was caused by an increased pressure on the cathode side, as shown in table 5. An increase in anode pressure from $1 \mathrm{~atm}$ to $2.5 \mathrm{~atm}$ also resulted in an increase in the fuel cell current density. An operating anode pressure of $2.5 \mathrm{~atm}$ and an operating cathode pressure that was greater than $2 \mathrm{~atm}$ produced an above-average current density of 1.6 $\mathrm{A} \mathrm{cm}^{-2}$ at a voltage of $0.6 \mathrm{~V}$. A study by You and Liu [24] showed that the operating pressure affects the performance of the fuel cell system. The study was conducted at an operating temperature of $353 \mathrm{~K}$, the cathode inlet velocity was $0.6 \mathrm{~ms}^{-1}$, and the anode pressure was $1 \mathrm{~atm}$ while the cathode pressure was $1.2 \mathrm{~atm}$ or $3 \mathrm{~atm}$. The results showed that an increasing cathode pressure resulted in the generation of an increased current density. Figs. $3 \mathrm{c}$ and $3 \mathrm{~d}$ show the performance of single cells by varying the anode pressure from $1 \mathrm{~atm}$ to $2.5 \mathrm{~atm}$, while the pressure at the cathode was either $1 \mathrm{~atm}$ or $2.5 \mathrm{~atm}$, showing that an increased anode pressure improved the single cell performance. The current density at a voltage of $0.6 \mathrm{~V}$ is shown in table 6 . An increase in the anode pressure from 1 atm to 2.5 atm while the cathode pressure was maintained at $1 \mathrm{~atm}$ resulted in a slight increase in the current density. At a cathode pressure of 2.5 atm, there was a significant increase in the current density. 


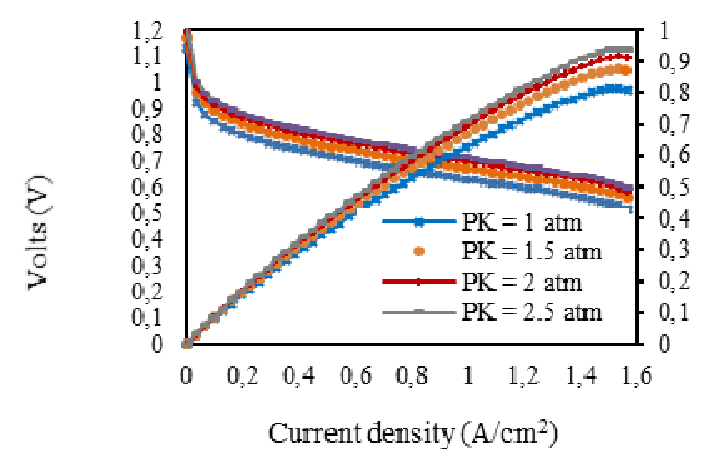

(a)

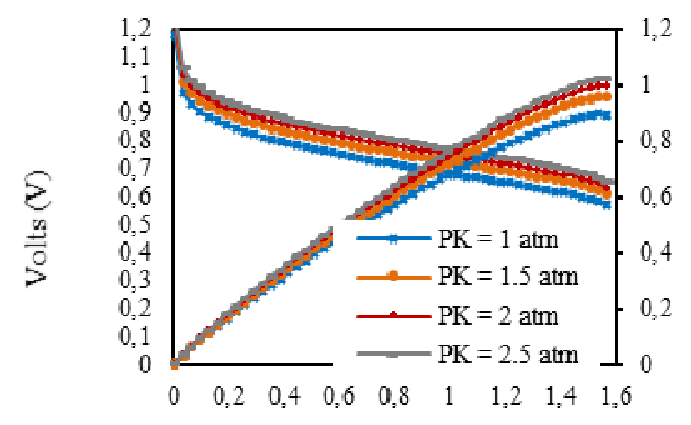

Current density $\left(\mathrm{A} / \mathrm{cm}^{2}\right)$

(b)

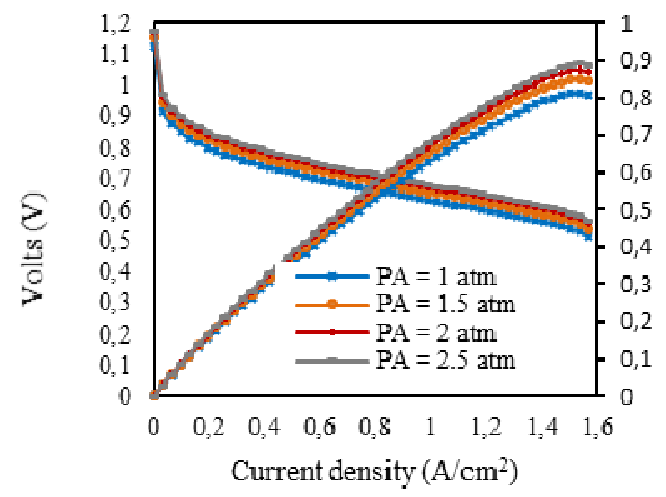

(c)

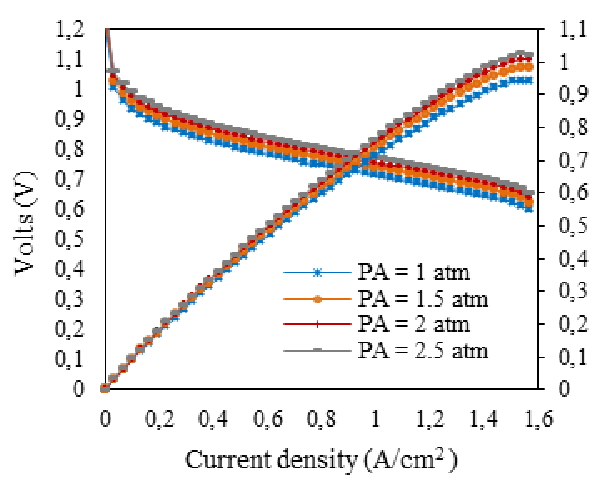

(d)

Fig. 3 Effect of pressure on single cell performance of PEMFC at temperatures of $353 \mathrm{~K}$, RHA is $75 \%$ and RHC is $90 \%$, the stoichiometric ratio is 1.2 for $\mathrm{H} 2$ and $\mathrm{O} 2$ are 2: (a) $\mathrm{PA}$ is 1 atm and $\mathrm{PC}$ are $1,1.5,2,2.5$ atm. (b) PA is $2.5 \mathrm{~atm}$ and PC are 1, 1.5, 2, $2.5 \mathrm{~atm}$. (c) PA are 1, 1.5, 2, 2.5 atm and PC is 1 atm. (d) PA are 1, 1.5, 2, 2.5 atm and PC is 2.5 atm

\section{Effect of the Stoichiometric Ratio of Reactants}

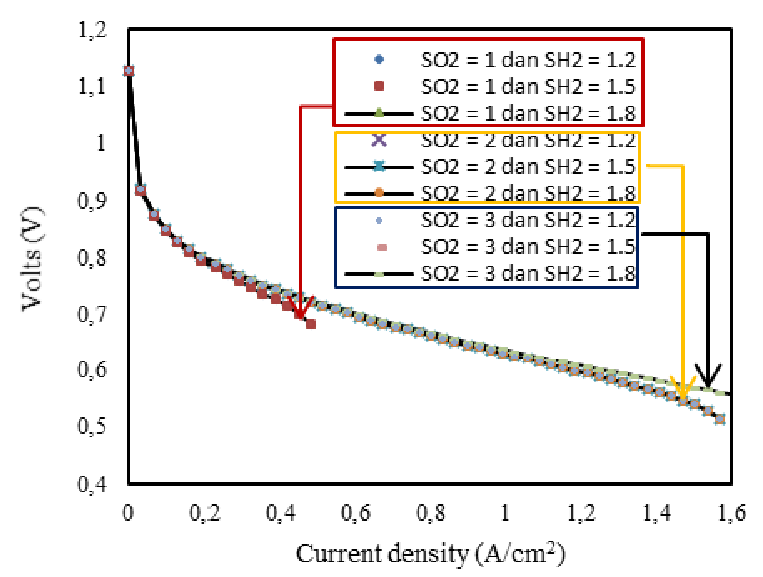

Fig. 4 Effect of stoichiometric ratio on single cell performance of PEMFC at temperatures of $353 \mathrm{~K}, \mathrm{RHA}$ and RHC is $75 \%$ and $90 \%, \mathrm{PA}$ and $\mathrm{PC}$ is 1 atm. The stoichiometric ratio of $\mathrm{H} 2$ is 1.2 to 1.5 and 1.8 , for $\mathrm{O} 2$ is $1,1.5,2$, 2.5 and 3

Fig. 4 shows the single cell performance at an oxygen stoichiometric ratio of 1,2 and 3 , while the hydrogen stoichiometric ratio was varied from 1.2 to 1.8 . The results of this study show that an increased hydrogen stoichiometric ratio did not influence the single cell performance significantly [25]. The oxygen stoichiometric ratio that is greater than 2 can achieve the maximum current density while the hydrogen stoichiometric ratio is maintained between 1.2 and 1.8 .

\section{E. Comparison of Single Cell Performance}

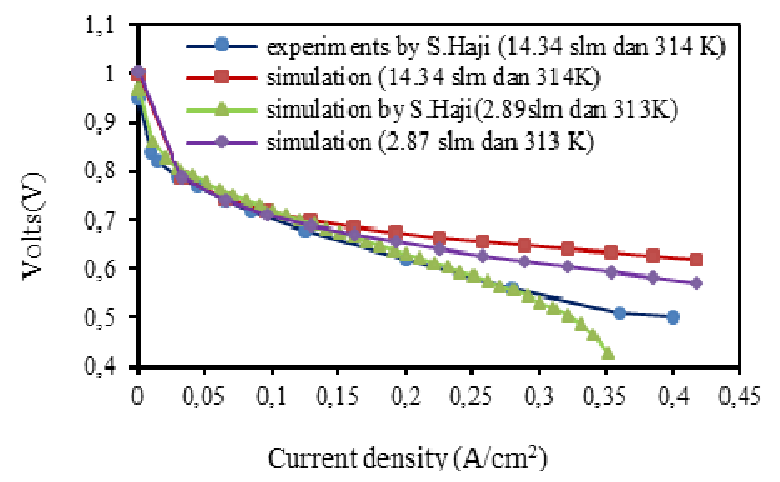

(a)

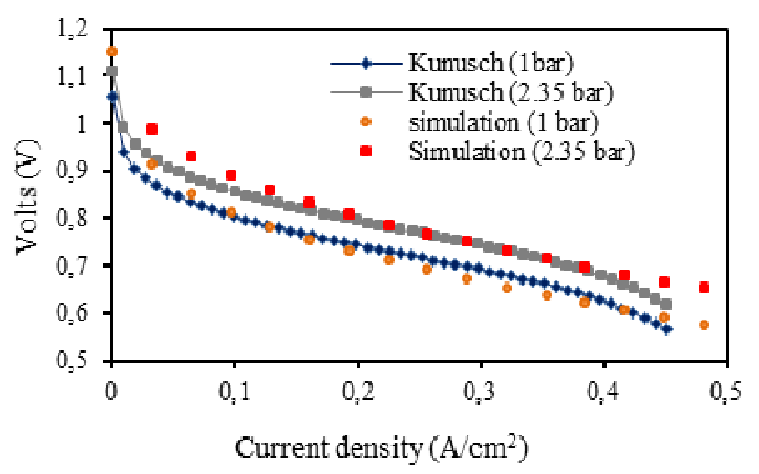

(b)

Fig. 5 Comparison of single cell performance of PEMFC with the investigation results of the investigation has been made: (a) comparison 
with the results of the investigation S.Haji 2011. (b) comparison with the results of the investigation Kunusch 2010

The results of this study were compared with an experimental and a simulation study conducted by S. Haji [20]. Experiments were conducted data flow rate of 14.34 slm and a temperature of $314 \mathrm{~K}$, while the simulations were conducted at a flow rate of $2.89 \mathrm{slm}$ and a temperature of 313K. Fig. 5a shows that the simulation study conducted by Haji showed a similar trend with their experimental data, while the simulation in this study showed a better performance than the simulation generated by Haji. At a flow rate of $2.87 \mathrm{slm}$ and a temperature of $313 \mathrm{~K}$, the simulation performance in this study was better than the simulation performance reported by Haji. Fig. 5b shows the comparison of the simulation results with the simulation study by Kunush [26]. The operating pressures for simulating the performance were 1 bar and 2.35 bar. The simulation results showed a trend similar to the performance of the single cell. However, the simulation results in this study showed no significant performance decrease beyond a current density of $0.45 \mathrm{Acm}^{-2}$, while the simulation results provided by Khunush showed a significant decrease.

\section{CONCLUSIONS}

The conclusions that can be drawn from this study, which conducted to determine the effect of several parameters on the performance of single-cell PEM fuel cells, are as follows:

- An increase in the temperature from $333 \mathrm{~K}$ to $353 \mathrm{~K}$ resulted in a significant improvement in the performance of a single PEM fuel cell. However, a subsequent increase in the temperature from $353 \mathrm{~K}$ to $363 \mathrm{~K}$ only resulted in a small improvement in the single cell performance.

- At the same relative humidity conditions on one side of the stack PEM fuel cell, an increase in the RHC exerted more influence on the single cell performance than an increase in the RHA. The best performance of the cell was 0.6 volts at an RHC from $70 \%$ to $90 \%$ and an RHA of $70 \%$.

- An increase in the cathode pressure improved the cell performance more significantly than an increase in the anode pressure. The maximum voltage achieved at an anode pressure of $1 \mathrm{~atm}$ and a cathode pressure $2.5 \mathrm{~atm}$ was 0.6 volts.

- An increase in the load mass of Pt from $0.2 \mathrm{mg}$ to 0.6 $\mathrm{mg}$ improved the performance of single cells, but a subsequent increase from $0.6 \mathrm{mg}$ to $1 \mathrm{mg}$ did not affect the performance significantly.

\section{NOMENCLATURE}

a The surface area to unit volume ratio of $\mathrm{cm}^{2} / \mathrm{cm}^{2}$ the catalyst layer

$\pi_{2}$ The total surface area of the catalyst $\quad \mathrm{cm} / \mathrm{g}$ per unit mass of catalyst

b. The Tafel constant

c Concentration

mol
$D_{\text {i. }}$ Binary diffusion coefficient of $\mathrm{O}_{2}$ in $\mathrm{N}_{2}$

E Electrical potential

$E^{\circ} \quad$ Electrical potential at standard conditions

$E_{\bar{\tau}} \quad$ Electrical potential of PEM fuel cells

F $\quad$ Faraday constant

96,485

$\mathrm{C} / \mathrm{mol}$

electrons

G Gibbs free energy

$H$ Enthalpy

$H_{z} \quad$ Hydraulic diameter

$h_{m} \quad$ Convective mass transfer coefficient

i Current density

$t_{0} \quad$ Exchange current density

$i_{\text {I }} \quad$ Limiting current density

$i_{g \rightarrow a f}$ Reference current density

$\therefore \quad$ Reaction rate constant

L Thickness of catalyst

$m_{z:}$ Catalyst load

$n$ The number of electrons per hydrogen molecule

F Pressure

$F_{1} \quad$ Partial pressure

$Q$ Charge

E. Universal gas constant

Reaction rate

$\mathrm{J} / \mathrm{mol}$

$\mathrm{J}$

$\mathrm{cm}$

$\mathrm{m} \mathrm{s}^{-1}$

$\mathrm{A} \mathrm{cm}^{-2}$

$\mathrm{A} \mathrm{cm}^{-2}$

$\mathrm{A} \mathrm{cm}^{-2}$

$\mathrm{A} \mathrm{cm}^{-2}$

$\mathrm{cm}$

$\mathrm{gr} / \mathrm{cm}^{2}$

$B H$ Average relative humidity

$R H_{s, i}$ Relative humidity of the reactants flow into the cathode side

$R_{\mathrm{s} m \mathrm{~m}}$ Resistance in the cell

$s \quad$ Entropy

shy Sherwood number

$T$ Temperature

$t_{m} \quad$ Dry membrane thickness

$\tau_{r s i}$ Reference temperature

$v \quad$ Voltage

$w_{e 1} \quad$ Maximum electrical work

Y Pt percentage

atm

atm

Coulombs

/ mol

$\mathrm{J} / \mathrm{mol} \mathrm{K}$

$\mathrm{mol} / \mathrm{cm}^{2} \mathrm{~s}$

Greek letters

$\alpha \quad$ Exchange coefficient

$\sigma_{\mathrm{ma}} \quad$ Membrane proton conductivity $\quad \mathrm{S} \mathrm{cm}^{-1}$

$\Delta \quad$ Delta

$\begin{array}{ll}\text { Subscripts } \\ \text { sot } & \text { Activation } \\ \text { con } & \text { Concentration } \\ f & \text { Forward } \\ b & \text { Backward } \\ \text { imrew } & \text { Irreversible } \\ \text { ohm } & \text { Ohmic } \\ \text { oper } & \text { Operation } \\ \text { rev } & \text { Reversible }\end{array}$

$\mathrm{J} / \mathrm{g} \mathrm{K}$

$\mathrm{K}$

$\mathrm{cm}$

$\mathrm{K}$

V

$\mathrm{J} / \mathrm{mol}$

$\%$

\section{ACKNOWLEDGEMENT}

The authors would like to thank the Department of Chemical Engineering Bung Hatta University for supporting this project 


\section{REFERENCES}

[1] B. G. Pollet, et al., "1 - Proton exchange membrane fuel cells A2 Barbir, Frano," in Compendium of Hydrogen Energy, A. Basile and T. N. Veziroğlu, Eds., ed Oxford: Woodhead Publishing, 2016, pp. 3 56.

[2] Mulyazmi, et al., "Design Models of Polymer Electrolyte Membrane Fuel Cell System," Key Engineering Materials, vol. 447-448, pp. 554-558, 2010

[3] Mulyazmi, et al., "Water balance for the design of a PEM fuel cell system," International Journal of Hydrogen Energy, vol. 38, pp. 9409-9420, 2013.

[4] D. N. Ozen, et al., "Effects of operation temperature and reactant gas humidity levels on performance of PEM fuel cells," Renewable and Sustainable Energy Reviews, vol. 59, pp. 1298-1306, 2016.

[5] M. Rahimi-Esbo, et al., "Improving PEM fuel cell performance and effective water removal by using a novel gas flow field," International Journal of Hydrogen Energy, vol. 41, pp. 3023-3037, 2016.

[6] Z. Abdin, et al., "PEM fuel cell model and simulation in MatlabSimulink based on physical parameters," Energy, vol. 116, Part 1, pp. 1131-1144, 2016.

[7] J. A. Salva, et al., "Optimization of a PEM fuel cell operating conditions: Obtaining the maximum performance polarization curve," International Journal of Hydrogen Energy, vol. 41, pp. 19713-19723, 2016.

[8] M. M. Barzegari, et al., "Dynamic modeling and validation studies of dead-end cascade $\mathrm{H} 2 / \mathrm{O} 2$ PEM fuel cell stack with integrated humidifier and separator," Applied Energy, vol. 177, pp. 298-308, 2016.

[9] Mulyazmi, "The Relationship Between PEM Fuel Cell Performance and Liquid Water Formation in The Anode and Cathode," Scientific Journal of PPI-UKM, vol. 2, p. 10, 2015.

[10] V. Liso, et al., "Modeling and experimental validation of water mass balance in a PEM fuel cell stack," International Journal of Hydrogen Energy, vol. 41, pp. 3079-3092, 2016.

[11] A. Haghighat Mamaghani, et al., "Predictive modelling and adaptive long-term performance optimization of an HT-PEM fuel cell based micro combined heat and power (CHP) plant," Applied Energy.

[12] Y. Ding, et al., "Numerical investigation of the impact of two-phase flow maldistribution on PEM fuel cell performance," International Journal of Hydrogen Energy, vol. 39, pp. 469-480, 2014.
[13] D. Song, et al., "Numerical optimization study of the catalyst layer of PEM fuel cell cathode," Journal of Power Sources, vol. 126, pp. 104111, 2004.

[14] D. Song, et al., "A method for optimizing distributions of Nafion and Pt in cathode catalyst layers of PEM fuel cells," Electrochimica Acta, vol. 50, pp. 3347-3358, 2005.

[15] G. Inoue, et al., "Evaluation of the optimal separator shape with reaction and flow analysis of polymer electrolyte fuel cell," Journal of Power Sources, vol. 154, pp. 18-34, 2006.

[16] D. Bezmalinovic, et al., "Characterization of PEM fuel cell degradation by polarization change curves," Journal of Power Sources, vol. 294, pp. 82-87, 2015.

[17] R. F. Mann, et al., "Application of Butler-Volmer equations in the modelling of activation polarization for PEM fuel cells," Journal of Power Sources, vol. 161, pp. 775-781, 2006.

[18] J. Zhang, et al., "PEM fuel cell relative humidity (RH) and its effect on performance at high temperatures," Electrochimica Acta, vol. 53, pp. 5315-5321, 2008.

[19] S. Rakhshanpouri and S. Rowshanzamir, "Water transport through a PEM (proton exchange membrane) fuel cell in a seven-layer model," Energy, vol. 50, pp. 220-231, 2013.

[20] H. Shaker, "Analytical modeling of PEM fuel cell i-V curve," Renewable Energy, vol. 36, pp. 451-458, 2011.

[21] C. Spiegel, "PEM Fuel Cell Modeling and Simulation Using MATLAB," Elsevier Inc, 2008.

[22] R. R. B. Tavakoli, "The effect of fuel cell operational conditions on the water content distribution in the polymer electrolyte membrane," Renewable Energy, vol. XXX, p. 13, 2011.

[23] A. C. O. Shamardina, A.A. Kulikovsky, A.R. Khokhlov, "A simple model of a high temperature PEM fuel cell," $\mathrm{j}$ o u $\mathrm{r}$ n a l of hydrogen energy, vol. 35, p. 8, 2010.

[24] L. You and H. Liu, "A two-phase flow and transport model for PEM fuel cells," Journal of Power Sources, vol. 155, pp. 219-230, 2006.

[25] L. Xing, et al., "Numerical study of the effect of relative humidity and stoichiometric flow ratio on PEM (proton exchange membrane) fuel cell performance with various channel lengths: An anode partial flooding modelling," Energy, vol. 106, pp. 631-645, 2016.

[26] C. Kunusch, et al., "Characterization and experimental results in PEM fuel cell electrical behaviour," International Journal of Hydrogen Energy, vol. 35, pp. 5876-5881, 2010. 